\title{
ANALISIS PENYIDIKAN POLRI TERHADAP TINDAK PIDANA PENGANIAYAAN DI WILAYAH POLRES MAMASA
}

\author{
Dedi Yulianto ${ }^{1}$, Ruslan Renggong ${ }^{2}$, Baso Madiong ${ }^{2}$ \\ ${ }^{1}$ Kepolisian Resort Mamasa \\ ${ }^{2}$ Program Studi Ilmu Hukum Program Pascasarjana Universitas Bosowa \\ Email: dedyyulianto144@yahoo.com \\ Diterima: 10 Januari 2021/Disetujui: 01 Juni 2021
}

The Analysis of the Role of Police Investigators in Investigating a Crime in Mamasa Police Office

\begin{abstract}
ABSTRAK
Tujuan dari penelitian ini, yaitu untuk mengetahui bagaimana optimalisasi peran Penyidik Polri dalam penyidikan suatu tindak pidana, dan untuk mengetahui apa saja kendala-kendala penyidik Polri dalam menjalankan tugas dan fungsinya sebagai penyidik. Jenis penelitian yang digunakan adalah penelitian kualitatif deskriptif normatif. Penelitian ini dilakukan di Polres Mamasa. Fokus pada penelitian ini adalah tindak pidana penganiayaan. Data dikumpulkan dengan teknik penelitian pustaka, penelitian lapangan. Kemudian data diolah dengan tahapan Editing, Coding, dan Tabulating. Selanjutnya data dianalisis dengan model interaktif, yaitu dimulai dengan pengumpulan data, reduksi, penyajian data dan penarikan kesimpulan. Hasil penelitian menunjukkan bahwa dalam kasus tertentu penyidik mempunyai peran meneruskan ke proses hokum atau kasus itu diselesaikan melalui pendekatan restorative justice. Kemudian kendala yang dihadapi penyidik adalah ketika proses restorative justice yang ditempuh terkendala oleh pihak keluarga korban yang tidak bersedia melakukan perdamaian yang ditandai dengan adanya surat pernyataan yang meminta agar pelaku dapat dihukum dan diproses layaknya pelaku dewasa.
\end{abstract}

Kata Kunci: Penyidik, Tindak Pidana, Penganiayaan

\begin{abstract}
The purpose of this research is to find out how to optimize the role of Police Investigators in investigating a crime, and to find out what are the obstacles for the Police investigators in carrying out their duties and functions as an investigator. This type of research is qualitative descriptive normative research. This research was conducted at Mamasa Police Station. The focus of this research is on the criminal act of maltreatment. Data were collected using library research and field research. Then the data is processed through the stages of editing, coding, and tabulating. Furthermore, the data were analyzed using an interactive model, starting with data collection, reduction, data presentation and drawing conclusions. The results show that in certain cases an investigator has a role to continue to the legal process or the case is resolved through a restorative justice approach. Then the obstacle faced by investigators is when the restorative justice process is constrained by the victim's family who is not willing to bury the hatchet which is marked by a statement letter asking that the perpetrator must be punished and processed like an adult perpetrator
\end{abstract}

Keywords: Investigators, Criminal Act, Persecution

\section{PENDAHULUAN}

Proses globalisasi serta pembangunan bisa menyebabkan kemajuan didalam kehidupan masyarakat. Selain itu juga dapat mengakibatkan perubahan sosial didalam masyarakat, yang mana pada dasarnya kehidupan ini tidak terlepas dari perubahan terhadap suatu lingkungan, baik lingkungan biologis maupun lingkungan sosial masyarkat. Pengertian dari perubahan sosial itu sendiri Antara lain perubahan-perubahan sosial merupakan suatu variasi dari cara-cara hidup yang telat diterima yang disebabkan baik karena perubahan-perubahan kondisi geografis, kehidupan materiil, komposisi penduduk, ideology maupun adanya difusi ataupun penemuan-penemuan baru dalam masyarakat tertentu.
Faktor masyrakat juga dapat mempengaruhi penegakan hukum itu sendiri, sebab penegakan hukum berasal dari masyarakat dan bertujuan untuk mencapai kedamaian dimasyarakat. Dalam hal ini yang penting adalah kesadaran hukum masyarakat. Semakin tinggi kesadaran hukum masyarakat, semakin baik pula penegakan hukum, sebaliknya semakin rendah tingkat kesadaran hukum masyarakat maka semakin sulit melaksanakan penegakan hukum yang baik.

Kesadaran hukum merupakan pandangan hukum dalam masyarakat tentang apa hukum itu. Pandangan itu berkembang dan dipengaruhi oleh berbagai faktor yaitu agama, ekonomi, politik dan sebagainya. Pandangan itu selalu berubah oleh karena hukum itu selalu berubah juga. Perubahan sosial itu 
sendiri adalah dimana hal ini selain membawa dampak positif juga membawa dampak negative, dampak negative dari pada perubahan sosial ini juga menambah kearah perkembangan tindak kejahatan terutama dalam hukum pidana yang salah satunya tindak pidana penganiayaan. Penganiayaan diartikan sebagai perubahan yang dilakukan dengan sengaja untuk menimbulkan rasa sakit (pijn) atau luka (letsel) pada tubuh orang lain.

Dari berbagai konflik yang dihadapi dewasa ini telah dilakukan berbagai formula baik yuridis maupun non yuridis, yang maksud dan tujuan akhirnya hendak melindungi kepentingan anak yang bersangkutan karena apapun alasannya anak dalam hal ini bukanlah miniature orang dewasa sehingga dalam setiap konflik yang melibatkannya maka anak senantiasa dalam posisi yang lebih banyak dirugikan padahal anak yang melakukan tindak pidana tersebut, sebenarnya tidak hanya sebagai pelaku tapi juga korban dari kegiatan kehidupan masyarakat yang heterogen. Diantaranya adalah membentuk seperangkat aturan hukum yang mengatur tentang kedudukan dan perlindungan anak yang berhadapan dengan hukum.

Penjelasan umum atas Undang-Undang Nomor 11 Tahun 2012 Tentang Sistem Peradilan Pidana Anak, menentukan bahwa anak adalah bagian yang tidak terpisahkan dan keberlangsungan hidup manusia dan keberlangsungan sebuah bangsa dan Negara, dalam konstitusi Indonesia anak memiliki peran strategis yang secara tegas dinyatakan bahwa Negara menjamin hak setiap anak atas kelangsung hidup, tumbuh, dan berkembang serta atas perlindungan dari kekerasan dan diskriminasi. Oleh karena itu kepentingan terbaik bagi anak patut dihayati sebagai kepentingan terbaik bagi kelangsungan hidup umat manusia. Konsekuensi dari ketentuan PAsal 28B Undang-Undang Dasar Negara Republik Indonesia Tahun 1945 perlu ditindaklanjuti dengan membuat kebijakan pemerintah yang bertujuan melindungi Anak.

Dalam upaya memberikan perlindungan terhadap kepentingan dan hak-hak anak yang berhadapan dengan hukum, pemerintah Indonesia telah mengeluarkan beberapa peraturan perundang-undangan terkait, Antara lain UndangUndang Republik Nomor 35 Tahun 2014 Tentang Perubahan Atas Undang-Undang Nomor 23 Tahun 2002 Tentang Perlindungan Anak. Ketentuan dalam Undang-Undang Nomor 35 Tahun 2014 menegaskan bahwa Perlindungan Anak adalah segala kegiatan untuk menjamin dan melindungi Anak dan hak-haknya agar dapat hidup, tumbuh, berkembang dan berpartisipasi secara optimal sesuai dengan harkat dan martabat dan martabat kemanusiaan serta mendapat perlindungan dari kekerasan dan diskriminasi.

Seiring dengan kemajuan masyarakat maka kejahatan semakin canggih dan semakin bervariasi modus operandi-nya yang terkadang belum ditemukan aturan hukumnya sehingga dapat dikatakan ibarat orang sedang berlari, hukum seperti tertatih-tatih mengejar perkembangan zaman dan terkadang apa yang diatur dalam Kitab Undang-Undang Hukum Pidana (KUHP) tidak mampu lagi memback up perbuatan melawan hukum tertentu sehingga untuk mengantisipasinya diperlukan pengaturan khusus terhadap perbuatan dimaksud.

Aturan dan sanksi walaupun telah diterapkan tindak pidana Penganiayaan tetap saja hanya terjadi. Hal ini dibuktikan dengan jumlah kasus penganiayaan di Daerah Mamasa yang menunjukkan angka yang signifikan sepanjang tahun 2014 sampai dengan 2020, yang dapat dilihat pada data Kepolisian Resor Mamasa, namun yang berhasil diselesaikan adalah sebanyak 369 kasus. Berdasarkan banyaknya kasus penganiayaan yang terjadi diwilayah hukum Polresta Mamasa yang paling menjadi sorotan publik adalah kasus tindak pidana penganiayaan akibat mnuman beralkohol dan terjadilah perkelahian. Karena didalam aksi pelaku hanya melukai korban.

\section{METODE}

Jenis penelitian yang digunakan adalah penelitian kualitatif deskriptif normatif yaitu menggambarkan secara jelas objek yang menjadi permasalahannya tanpa bermaksud mengambil kesimpulan yang berlaku secara umum. Dengan menggunakan penelitian kualitatif deskriptif di bidang hukum, maka penelitian ini berusaha menggambarkan peristiwa inconcreto untuk dikonsultasikan dengan seperangkat norma hukum positif yang berlaku, yang ada kaitannya dengan masalah yang menjadi objek penelitian

Lokasi Penelitian ini dilakukan di Polres Mamasa. Fokus pada penelitian ini terdiri atas: Tindak pidana, penyidik dan penganiayaan. Sebagai tindak lanjut dalam memperoleh datadata sebagaimana yang diharapkan, maka penulis melakukan teknik pengumpulan data yang berupa penelitian Pustaka (library research) dan penelitian lapangan (field research).

Pengolahan data dilaksanakan melalui tahap:

1. Editing adalah kegiatan yang dilaksanakan setelah peneliti selesai menghimpun data di lapangan.kegiatan ini menjdai penting karena kenyataannya data yang terhimpun kadang kala belum memenuhi harapan peneliti.

2. Coding adalah mengklasifikasi data-data yang ada. Maksudnya bahwa data yang telah diedit tersebut diberi identitas sehingga memiliki arti tertentu pada saat dianalisis.

3. Tabulating adalah bagian terakhir dalam pengolahan data. Maksud tabulasi adalah memasukkan data pada tabel-tabel tertentu dan mengatur angka-angka serta menghitungnya.

Proses analisis data dalam penelitian ini menggunakan teknik analisis data model interaktif Miles dan Huberman terdiri dari (1) Pengumpulan data, (2) Reduksi data, (3) Penyajian data, dan (4) Penarikan kesimpulan. Selanjutnya analisis tersebut dilakukan dengan memadukan cara interaktif terhadap ketiga komponen utama dimaksud. Untuk memperoleh tingkat keabsahan data peneliti menggunakan triangulasi yaitu mengadakan perbandingan antara sumber data yang satu dengan yang lain.

\section{HASIL DAN PEMBAHASAN}

\subsection{Optimalisasi Peran Penyidik Polri Dalam Melakukan Penyidikan Suatu Tindak Pidana Penganiayaan Yang Dilakukan Oleh Anak Di Wilayah Hukum Polres Mamasa}

Serangkaian tindakan penyelidik untuk mencari dan menemukan suatu peristiwa yang diduga sebagai tindak pidana guna menentukan suatu peristiwa yang diduga sebagai tindak guna menentukan dapat atau tidaknya dilakukan penyediklan, secara umum berdasarkan penyidikan terhadap pelaku tindak pidana anak hanya dapat dilakukan apabila pelaku tindak pidana telah berusia 8 (delapan) tahun tetapi belum mencapai umur 18 (delapan belas) tahun, terhadapa anak dibawah umur delapan tahun yang melakukan tindak pidana akan mendapat pembinaan dan dikembalikan pada orang tua/wali. 
Penyidikan terhadap anak dalam hal anak nakal dilakukan oleh Penyidikan Anak, yang ditetapkan berdasarkan Surat Keputusan Kepala Kepolisia RI atau Pejabat yang ditunjuk olehnya dengan demikian Penyidik umum tidak dapat melakukan penyidikan atas Perkara Anak Nakal kecuali dalam hal tertentu seperti belum ada Penyidik Anak ditempat Tersebut.

Adapun Syarat-Syarat untuk menjadi Penyidik Anak Sesuai Undang-Undang No. 3 Tahun 1997 adalah mempunyai minat, dedikasi dan memahami masalah anak, akan tetapi dalam hal-hal tertentu karena penyidik anak belum ada maka tugas penyidikan dapat dilakukan oleh penyidik biasa bagi tindak pidana yang dilakukan oleh orang dewasa ataupun penyidik lain yang ditetapkan berdasarkan Undang-Undang yang berlaku.

Penyidikan terhadap anak nakal berlangsung dalam suasana kekeluargaan dan untuk itu penyidik wajib meminta pertimbangan atau saran dari Pembimbing Kemasyarakatan sesuai Undang-Undang N0.3 Tahun 1997 dalam suasana kekeluargaan berarti pada waktu memeriksa tersangka anak, penyidik tidak memakai pakaian seragam/dinas dan melakukan pendekatan secara efektif, aktif dan simpatik. Suasana kekeluargaan ketika penyidikan dilakukan adalah kehadiran orang tua/wali/orang tua asuhnya sangat penting agar timbul ketakutan atau trauma pada diri si Anak karena takutanya si Anak akan mengalami depresi, rasa malu dan akhirnya sukar diterima di lingkungannya.

Ibu atau wanita dipandang sebagai subjek yang langsung secara kodrati lebih memahami masalah anak secara komprehensif dalam masalah psikologis sainsis seperti temperamental, emosionalitas dan lingkungan social maupun masalah anak dalam psikologis kontemporer seperti watak, bakat, budaya, hobi dan lain-lain yang menjadi dasar eksistensi anak dalam lingkungan social.

Pada Pearturan Kabareskrim Polri No. 1 Tahun 2012 Tentang Standar Operasional Prosedur (SOP) Penanganan Anak yang berhadapan dengan hukum dilingkungan Bareskrim Polri disebutkan bahwa dalam penyelenggaraan Penyelidikan dan Penyedikan tidak pidana khususnya yang berkaitan dengan anak, penyidik harus memperhatikan hak asasi serta memberikan perlindungan terhadap anak.

Menurut wawancara Jhon Franklin (Kanit Reskrim Polres Mamasa), jika dalam melakukan tindak pidana Penganiayaan dimana usia anak kurang dari 8 (delapan) tahun maka cukup keterangan saja diambil dan berkas pemeriksaan tidak dikirim lalu anak dikembalikan kepada Orang Tua. Jika usia anak Antara 8 (delapan) tahun sampai kurang dari 12 (dua belas) tahun atau lebih maka berkas pemeriksaan akan dikirim kepada kejaksaan namun tetap diusahkan bahwa pidana hanya sebagai upaya yang paling akhir.

a. Penangkapan

Penangkapan adalah pengekangan sementara waktu kebebasan dilakukan apabila terdapat cukup bukti guna kepentingan penyedikan. Tindakan penangkapan anak yang berhadapan dengan hukum harus memperhatikan hak-hak anak dengan mengadakan tindakan menurut hukum yang bertanggung jawab, sebagai berikut:

1) Anak yang diduga melakukan tindak pidana harus diperlakukan dengan asas praduga tak bersalah;

2) Anak yang berhadapan dengan hukum diperlakukan dengan arif, santun dan bijaksana dan tidak diperlakukan sebagai orang dewasa pelaku tindak pidana;
3) Saat melakukan penangkapan terhadap anak, segera memberitahukan orang tua atau walinya;

4) Apabila penangkapan dilakukan karena anak, segera memberitahukan orang tua atau walinya;

5) Dalam melaksanakan wewenang mengadakan tindakan lain menurut hukum yang bertanggung jawab. Polisi atau masyarakat tidak dibekali dengan surat perintah dan penyidik ketika ada anak yang diduga sebagai tersangka yang tertanggap tangan. Dalam hal ini polisi atau masyarakat hanya berdasar pada asas kewajibannya;

6) Penangkapan terhadap anak yang diduga sebagai tersangka, namun bukan karena tertangkap tangan, merupakan kontak atau tahap pertama Antara anak dengan polisi.

Menurut Drones Ma'dika, S.H (KBO Sat Preskrim Polres Mamasa), dasarnya dalam melakukan penangkapan terhadap anak yang melakukan tindak pidana, petugas polisi tidak berpakaian seragam melaikan pakaian biasa (Preman) dalam hal ini penyedik juga tidak mengalami banyak kesulitan, terlebih-lebih terhadap anak yang baru pertama kali melakukan tindak pidana, karena kebanyakan dari mereka masih polos dann jujur setelah tersangka (anak yang melakukan tindak pidana) maka terhadapnya dilakukan pemeriksaan, berdasarkan ketentuan Undang-Undang No. 3 Tahun 1997 pemeriksaan dapat dilakukan dengan ketentuan sebagai berikut:

a) Penyidik wajib memeriksa tersangka dalam suasana kekeluargaan;

b) Dalam melakukan Penyidikan terhadap anak yang melakukan tindak pidana wajib meminta pertimbangan atau saran dari ahli kesehatan jiwa, ahli agama atau petugas kemasyarakatan lainnya;

c) Proses penyidikan terhadap perkara anak nakal wajib dirahasiakan.

Pemeriksaan dimaksudkan untuk dapat menentukan perlu tidaknya diadakan oleh Kitab Undang-Undang Hukum Acara Pidana hanya 1 x 24 jam.

Pada tahap penangkapan terhadap anak yang diduga sebagai tersangka, namun bukan karena tertangkap tangan penting bagi seorang Polisi untuk menghindari anak dari pengalaman-pengalaman traumatic yang akan dibawah oleh anak seumur hidupnya untuk menghidari hal tersebut, polisi harus memperhatikan hal-hal sebagai berikut:

1) Menghindari menggunakan kata-kata kasar dan nada tinggi yang akan menarik perhatian orang-orang yang ada disekeliling anak;

2) Membimbing anak dengan menggandeng tangannya tidak memegang kerah baju anak atau menyeret;

3) Tidak memerintahkan anak melakukan hal-hal yang mempermalukan dan merendahlan harkat dan martabatnya sebagai manusia misalnya menyuruhnya membuka pakaian;

4) Menghindari penggunaan borgol atau memborgol tangannya;

5) Mengamankan anak dari pelipitan media massa baik cetak maupun elektronik.

b. Wawancara dan Penyidikan

Wawancara dan penyidikan merupakan aspek yang sangat penting dari pelaksanaan tugas setiap Polisi dalam mengungkap suatu kasus yang melibatkan anak. Khususnya dalam menangani kasus anak yang berkonflik dengan hukum (baik sebagai pelaku, korban, maupun saksi), orang 
tua, saksi dan Orang-orang lain yang diperlukan atau berkaitan dengan kasus tersebut secara berkesinambungan.

Langkah-langkah yang dapat membantu Polisi dalam melaksanakan wawancara secara efektif dan efisien adalah sebagai berikut:

1) Dalam wawancara anak harus didampingi oleh orang yang terdekat dengan anak tersebut dan yang paling ia percaya (bisa orangtua, saudara, pengasuhnya, pekerjaa social, dsb) sehingga dapat membantu kelancaran wawancara;

2) Menggunakan Bahasa yang jelas dan mudah dan dimengerti oleh anak yang bersangkuta dan pendampingannya;

3) Menghindari penekanan, kebohongan, intimidasi atau perlakuan keras dan kasar terhadap anak selama wawancara berlangsung;

4) Wawancara dilaksanakan dalam ruangan yang nyaman dan terpisah dari orang dewasa lainnya sehingga anak tidak merasa ketakutan.

Adapun teknik dasar melakukan wawancara terhadap anak yang harus dilakukan oleh Penyidik atau Polisi adalah:

1) Menginformasikan kepada Orangtua atau Wali yang bersangkutan harus segera diberi informasi bahwa anaknya akan diwawancara;

2) Memberikan informasi tentang bantuan hukum, Anak dan Orang tua atau walinya harus diberitahu mengenai pentingnya anak didampingi oleh penasehat hukum dan pekerja sosial yang berkompeten dan bagaiman cara mengakses bantuan-bantuan tersebut;

3) Memperlakukan anak dengan pertimbangan panjang harus mengingat bahwa apa yang akan dilakukan kepada si anak dapat mempengaruhi tingkah laku anak di masa depan;

4) Membangun keakraban yaitu cata tidak melakukan halhal yang dapat membentuk tingkah laku anti sosial pada anak sehingga anak-anak putus asa dalam menghadapi hidup karena mereka merasa kehilangan hari depan yang lebih baik;

5) Membangun akan mempermudah mendapatkan informasi dari anak tersebut;

6) Memperkenalkan diri dengan benar, hal ini akan membantu dalam memfasilitasi wawancara;

7) Melakukan wawancara sesegara mungkin setelah anak ditanggap atau ditahan, hal ini akan menunjukkan keseriusan dan menjaga anak dalam membangun alibinya;

8) Mengatakan kepada anak bahwa ingin membantuhnya hal ini dilakukan dengan tujuan agar anak tahu bahwa penyidik ingin bekerjasama dan peduli terhadap hari depannya;

9) Berbicara dengan Bahasa yang muda dimengerti menggunakan Bahasa yang mudah dimengerti oleh anak yang bersangkutan jika mungkin gunakan istilah-istilah yang popular diantara anak-anak;

10) Mengajak anak untuk mau berbicara pada umumnya anak akan tertarik pada diskusi tentang hal-hal yang menarik atau digemarinya. Hal ini akan membantuhnya merasa tenang dan nyaman;

11)Menjadi pendengar yang baik konsentrasi dalam wawancara sehingga anak akan merasa diperhatikan dengan sungguh-sungguh. Hindarkan mengalihkan perhatian kepada orang lain selama wawancara berlangsung;
12) Menghormati kepribadian anak perlakukan anak sebagai orang yang;

13)Berharga, bermartabat, sebagai seseorang yang memerlukan bantuan dan pengertian;

14)Mengizinkan anak menulis ceritanya meninggalkan anak sendirian untuk melakukan ini apabila diperkirakan akan aman penahan

c. Penahanan

Penahanan adalah pengekangan fisik sementara terhadap seorang anak berdasarkan keputusan Penagdilan atau selama anak dalam proses menunggu pemindahan ke Pusat Rehabilitas yang dirujuk.

Adapun petunjuk-petunjuk yang harus diperhatikan untuk penahanan anak sebelum dinyayakan bersalah adalah sebagai berikut:

1) Sebisa mungkin untuk menghindari penahanan, polisi harus jeli melihat apakah kebutuhan terbaik bagi si Anak jika setelah mengevaluasi kondisi lingkungan sekitar anak da nada jaminan keamanan dilingkungan rumah anak maka penahanan rumah dapat dilakukan sesuai Keputusan Pengadilan;

2) Jika penahanan terpaksa dilakukan agar segera diberitahukan orangtua atau walinya dan rujuk orangtua/ wali si anak untuk mendapatkan bantuan hukum bagi anaknya;

3) Polisi harus selalu berkonsultasi dengan Pekerjaan Sosial dari Depsos yang berperan dalam menangani masalah anak;

4) Apabila anak disangka bersalah dan penahanan terpaksa dilakukan agar segera memberitahukan pihak sekolah dan buat perjanjian bahwa sekolah akan ikut bertanggung jawab menghindari gangguan terhadap anak tersebut dilingkungan sekolah;

5) Bila dalam pemeriksaan pengadilan ditemukan bahwa Orangtua/Wali maupun pihak lingkungan setemempat (seperti RT atau RW) dapat bertanggung jawab dan menjamin agar anak selalu hadir pada siding-sidang berikutnya maka penahanan dapat segera ditangguhkan;

6) Anak-anak harus diberikan Tahanan Rumah jika tidak memungkinkan mereka harus dipisahkan dari tahanan orang dewasa;

7) Anak berusia kurang dari 12 tahun dilarang untuk ditahan pada anak berusia lebih dari 12 tahun jika penahanan terpaksa dilakukan maka harus dipisahkan dari orang dewasa.

d. Pengeledahan

Pengeledahan dilakukan berdasarkan hasil laporan penyelidikan yang dibuat oleh petugas penyidik/penyidik pembantu untuk penggeledakan rumah hanya dapat dilakukan untuk kepentingan penyidikan guna menjamin hak asasi manusi atau seseorang atas rumah kediamannya, maka dalam melakukan penggeledahan harus dengan surat izin dari Ketua Pengadilan Negeri dan Surat Perintah penggeledahan dalam melakukan penggeledahan harus disaksikan oleh 2 (dua) orang saksi bila pemilik rumah memberikan izin untuk digeledah, jikalau dalam melakukan penggeledahan terdapat atau ditemukan barang bukti maka barang tersebut dapat disita untuk kepentingan penyidikan lebih lanjut dan anak yang melakukan tindak pidana tersebut dapat ditahan untuk kepentingan pengusutan kalau memang terbukti anak tersebut dapat diajukan sebagai terdakwa.

e. Penyitaan

Penyitaan adalah serangkaian tindakan penyidik untuk mengambil alih atau menyimpan untuk kepentingan 
pembuktian dalam penyidikan, penuntutan dan peradilan. Dalam hal tertanggap pembuktian dalam penyidikan, penuntutan dan peradilan dalam hal tertangkap tangan oleh petugas polisi maka barang bukti langsung dapat disita misalnya alat yang digunakan untuk melakukan tindak pidana

Dalam hal penggeledahan rumah penyitaan harus dilakukan dengan izin Ketua Pengadilan Negeri. Disamping itu yang dapat dikenakan penyitaan adalah:

1) Benda atau tagihan tersangka yang seluruh atau sebagaian diduga diperoleh dari hasil tindak pidana;

2) Benda yang telah dipergunakan secara langsung untuk melakukan tindak pidana atau untuk memperdiapkannya;

3) Benda yang dipergunakan untuk menghalang-halang penyidikan tindak pidana;

4) Benda yang khusus dibuat atau diperuntukkan melakukan tindak pidana;

5) Benda lain yang mempunyai hubungan langsung dengan tindak pidana yang dilakukan;

6) Benda yang berada dalam sitaan perkara perdata atau pailit sepanjang memenuhi ketentuan sebagaiman tersebut pada huruf a,b,c,d,e

f. Penyerahan Berkas Perkara

Setelah semua diperiksa oleh penyidik maka dilakukan pemeriksaan perkara atau berkas perkara, apabila belum lengkap maka dikembalikan untuk diperbaiki.

Peran penyidik dalam system peradilan pidana (anak) tahap penyidikan merupakan kontak awal (initial contact) untuk menangani kasus tersebut dengan kebijakan mereka tanpa melalui peradilan formal sesuai dengan criteria yang tercantum dalam tujuan system hukum yang berlaku dan sesuai dengan asas-asas dalam ketentuan lain. Agar perlindungan anak dapat diselenggarakan dengan baik dianut prinsip yang menyatakan bahwa kepentingan terbaik anak harus dipandang sebagai of paramount importence (memperoleh prioritas tertinggi) dalam setiap keputusan yang menyangkut anak tanpa prinsip ini perjuangan untuk melindungi anak akan mengalami banyak batu sandungan. Prinsip the interest of the child digunakan karena dalam banyak hal anak "korban".

Polisi sebagai garda terdepan dalam penegakan hukum memiliki tanggungjawab yang cukup besar untuk mensinergikan tugas dan wewenang Polri sebagaimana yang telah diatur dalam Undang-Undang Nomor 2 Tahun 2002 Tentang Kepolisian Negara Republik Indonesia yaitu bahwa Kepolisian Republik Indonesia memilioki tugas:

1) Memelihara Keamanan dan Ketertiban Masyarakat;

2) Menegakkan Hukum;

3) Memberikan Perlindungan, Pengayoman dan Pelayanan MAsyarakat.

Rumusan kewenangan tersebut merupakan kewenangan yang bersumber dari asas kewajiban umum kepolisian yaitu suatu asas yang memberikan kewenangan kepada aparat untuk bertindak ataupun tidak melakukan tindakan apapun berdasarkan penilaian pribadi sendiri dalam rangka kewajibannya menjaga, memelihara ketertiban dan menjaga keamanan umum. Kewenangan demikian dikenal dengan istilah diskresi kepolisian, yang keabsahannya didasarkan dan ini tergantung pada kemampuan sebjektifnya sebagai petugas.

Tahap penyidikan merupakan tahap yang penting diperhatikan karena pengaruh yang ditimbulkan bukan hanya dapat mennetukan keberhasilan dalam proses peradilan selanjutnya, melainkan juga membawa pengaruh terhadap perkembangan jiwa anak. Adanya ketentuan sebagaimana diatur dalam Pasal 42 UUPA bahwa penyidik "wajib"memeriksa tersangka dalam "suasana kekeluargaan" sejalan dengan ketentuan-ketentuan yang diatur dalam Beijing rules.

3.2. Kendala-kendala penyidik polri dalam menjalankan tugas dan fungsinya sebagai penyidik tindak pidana pengamiayaan di wilayah polres Mamasa

Pada dasarnya merupakan upaya pengalihan dari proses peradilan pidana menuju penyelesaian secara musyawarah yang pada dasarnya merupakan jiwa dari bangsa Indonesia untuk menyelesaikan permasalahan dengan cara kekeluargaan untuk mencapai mufakat. Hal ini sesuai dengan bunyi sila ke4 Pancasila yang berbunya "Kerakyatan yang dipimpin oleh Hikmat kebijaksanaan dalam Permusyawaratan/perwakilan" inti dari makna sila Ke4 Pancasila diatas dalam kaitannya yang dianut dalam rangka penyelesaian perkara pidana yang dilakukan oleh anak. Dalam suatu proses perkara pidana terdapat beberapa permasalahan-permasalahan yang menjadi suatu kendala penyidik untuk meningkatkan profesionalisme dalam melakukan penyidikan.

Dalam mewujudkan penegakan hukum itu diperlukan satu mata rantai suatu proses yang baik dan sistematis demi terwujudnya penegakan hukum yang baik diperlukan juga hubungan koordinasi yang baik antar aparat penegak hukum dengan berpedoman pada ketentuan perundang-undangan yang berlaku. Menurut Jhon Franklin selaku Kanit Reskrim Polsek Mamasa, beberapa kendala yang dihadapi penyidik Polri dalam proses penyidikan perkara pidana yang menghambat terlaksananya Peberapan Restorative Justice adalah:

a. Substansi hukum yang belum mengakomodir pelaksanaan keadilan restorative secara lengkap;

b. Penegakan hukum yang belum melaksanakan secara optimal peraturan yang sudah ada dan masih bersikap kaku dan kuktur hukum/partisipasi masyarakat yang belum maksimal;

c. Belum adanya pembuatan regulasi yang mengakomodir semua ketentuan tentang penanganan $\mathrm{ABH}$ melalui pendekatan keadilan restorative, sosialisasi ke semua aparat penegak hukum dan masyarakat;

d. Koordinasi antar aparat penegak hukum dan mengubah paradigm aparat penegak hukum dari pendekatan retributive dan restitutive jutice menjadi restorative justice belum sepenuhnya dapat tercapai.

Konsep Restorative Justice merupakan paradigm baru dalam penegakan hukum pidana meskipun sebenarnya konsep tersebut sudah lama berkembang dan dipraktikkan dalam penyelesaian perkara pidana di beberapa Negara yang menganut common law system. Karena konsep tersebut relative baru maka tidak heran apabila upaya penerapan konsep tersebut dalam praktik penegakan hukum pidana di Indonesia khusunya oleh Polres Mamasa banyak menemui kendala.

Salah satu kendalanya adalah rendahnya pemahaman anggota Polri terhadap konsep Restorative Justice. Anggota Polres Mamasa secara umum seiring mendengar penyebutan istilah Restorative Justice, tetapi pada kenyataannya tidak sedikit anggota yang belum paham dengan istilah tersebut apalagi menerapkannya karena konsep tersebut relative baru dalam penegakan hukum pidana. 
Terlebih lagi dalam UU Nomor 2 Tahun 2001 Tentang Polri hanya mengenalkan konsep diskresi kepolisian. Walaupun diskreasi sudah ada dalam Pasal 18 UU No.2 Tahun 2001 Tentang Polri sehingga peluang pada aparat kepolisian untuk menerapkan diskresi sebagai tindakan yang tidak menyimpan namun dalam praktik penyelenggaraan tugas-tugas kepolisian masih banyak aparat kepolisian yang ragu untuk menggunakan wewenang ini, terutama dalam penanganan kasus pidana selengkapnya Pasal 18 UU No 2 Tahun 2002 menyebutkan:

1) Untuk keperluan umum, pejabat Kepolisian Negara Republik Indonesia dalam melaksanakan tugas dan wewenangnya dapat bertindak menurut penilaiannya sendiri;

2) Pelaksanaan ketentuan sebagaiman dimaksud dalam ayat (1) hanya dapat dilakukan dalam keadilan yang sangat perlu dengan memperhatikan peraturan Perundangundangan serta Kode Etik Profesi Kepolisian Negara Republik Indonesia.

Selanjutnya, Penjelasan Pasal 18 Ayat (1) menyebutkan: Yang dimaksud dengan "bertindak menurut penilaiannya sendiri" adalah suatu tindakan yang dapat dilakukan oleh anggota Kepolisian Negara Republik Indonesia yang dalam bertindak harus mempertimbangkan manfaat serta resiko dari tindakannya dan betul-betul untuk kepentingan umum".

Dalam menerapkan atau mengimplementasikan konsep keadilan restorative penyidik Polri acap kali mengalami keragu-raguan dalam mengambil keputusannya pada proses penyidikan terutama apabila pelaku/keluarganya dan korban/keluarganya maupun masyarakat ternyata menginginkan perdamaian dalam penyelesaian kasus atau perkaranya.

Hal ini disebabkan karena tidak adanya aturan ataupun paying hukum maupun prosedur/mekanisme formal untuk mengakomodir hal tersebut sehingga situasi ini menjadi hal yang dilematis bagi penyidik Polres Mamasa dilapangan yang berdasarkan pada factor-faktor:

1) Kekawatiran atau ketakutan penyidik akan dipersalahkan oleh pimpinan atau atasan dan dipermasalahkan pada pengawasan dan pemeriksaan oleh institusi pengawasan dan pemeriksa internal Polres Mamasa yang menggunakan parameter formal procedural;

2) Tidak adanya paying hukum yang mengatur dan menjadi landasan litimasi dalam mengambil keputusan pada proses penyidikan apakah berdasarkan konsep Restorative Justice atau konsep pendekatan lain yang bersesuaian dengan aliran Sociological Juriprudence.

3) Tidak adanya prosedur atau mekanisme yang formal procedural untuk mengimplementasikannya.

Memahami konsep kewenangan anggota Kepoisian secara sederhana adalah memahami bahwa kewenangan anggota Polri untuk mengambil keputusan atau memilih berbagai tindakan dalam menyelesaikan perkara pidana yang ditanganinya dengan berdasarkan hukum atas dasar situasi dan kondisi menurut pertimbangan dan keputusan nuraninya sendiri demi kepentingan umum. Sedangkan Restorative Justice secara sederhana dapat dipahami sebagai filosofi pemindahan yang mendudukkan korban pada titik sentral dalam menyelesaikan perkara pidana dan menjauhkan pelaku kejahatan dari pemenjaraan melalui diversi, akan tetapi tetap diminta pertanggungjawabkan. Sebagai satu filosifi pemindahan maka dalam implementasinya membutuhkan suatu konsep yang memiliki legitimasi dalam aplikasinya.
Sebagai wujud aktualisasi dari filosfi tersebut maka konsep tersebut harus dituangkan dalam peraturan perundangundangan. Dengan adanya pengaturan Tentang diskresi Kepolisian dalam Pasal 18 Nomor 2 Tahun 2002 sebenarnya telah memberikan pijikan yuridis, polri untuk menerapkan filosofi Restorative Justice dalam penanganan perkara pidana. Dengan diskresi penyidik Polri dapat memilih berbagai tindakan dalam menyelesaikan perkara pidana yang ditanganinya salah satu tindakan yang dapat diambil dalam implementasikan Restorative Justice adalah dengan mendudukkan korban pada titik sentral dalam menyelesaikan perkara pidana dan menjauhkan dari pemenjaraan akan tetapi dimintai pertanggungjawabkan.

\section{KESIMPULAN DAN SARAN}

Hasil penelitian dan pembahasan dapat disimpulkan bahwa peran Penyidik dalam Pelaksanaan Pengalihan (diversi) adalah bahwa tidak semua kasus anak dapat diselesaikan melalui pendekatan restorative justice yaitu dengan cara pengalihan (diversi) terkhusunya tindak pidana dengan ancaman hukuman yang tidak dapat ditolerir seperti tindak pidana narkotika dan psikotropika. Dalam penyelesaian kasus anak juga harus ada persetujuan dari pihak korban agar dapat di upayakan penyelsaian namun dalam prakteknya terkadang dari pihak korban tidak menyetujui upaya perdamaian yang dilakukan oleh penyidik dan meneruskan ke proses hukum secara formal atau cara terbaik dalam penyelesaian kasus-kasus anak yang berkonflik dengan hukum demi penangan terbaik bagi anak. Kendala Penyidik dalam Proses penangan tindak pidana penganiayaan dengan Restorative Justice penyidik terkadang dilibatkan dan tidak dilibatkan namun apabila perkara tersebut sudah diselesaikan secara damai biasanya pihak korban, pelaku dan tokoh masyarakat atau pihak-pihak yang terlibat untuk meminta pendapat dan saran namun apabila didalam kasus-kasus tertentu seperti pencurian, perkelahian mengakibat kekerasan penganiayaan sampai dengan mengancam jiwa seseorang diminta korban atau orang keluarga korban biasanya mengancam jiwa seseorang dimana korban atau orang keluarga korban biasanya tidak bersedia melakukan perdamaian dengan adanya surat penyataan yang ditandatangani oleh pihak korban maka dalam kasus seperti ini akan dilanjutkan ketingkat.

\section{DAFTAR PUSTAKA}

Adami Chazawi. 2002. Pelajaran Hukum Pidana 1. Jakarta: Raja Grafindo Persada.

Adami Chazawi. 2005. Tindak Pidana Mengenai Kesopanan. Jakarta: PT Raja Grafind o Persada.

Ahmad Rifai. 2010. Penemuan Hukum Oleh Hakim Dalam Perspektif Hukum Progresif. Sinar Grafika. Jakarta.

Andi Hamzah. 1991. Asas-Asas Hukum Pidana. Jakarta: Rineka Cipta.

Andi Hamzah. Sistem Pidana dan Pemidanaan Indonesia, dari Retribusi ke Reformasi. Jakarta: Pradnya Paramita.

Andi Zainal Abidin Farid. 1995. Hukum Pidana I. Jakarta: Sinar Grafika,

Andi Zainal Abidin Farid. 2007. Hukum Pidana I. Jakarta, Penerbit : Sinar Garfika

Bambang Poernomo. 1993. Asas-Asas Hukum Pidana. Jakarta: Ghalia Indonesia

Barda Arief Nawawi. 1996. Bunga Rampai Kebijakan Hukum Pidana. Bandung: PT Citra Aditya Bakti. 
Ferdy, F., Mas, M., \& Siku, A. S. (2020). Analisis Penegakan Hukum Terhadap Pelaku Tindak Pidana Penyerobotan Tanah Yang Terjadi Di Wilayah Hukum Polda Sulawesi Selatan. Indonesian Journal of Legality of Law, 3(1), 611.

Ruslan Renggong. 2016. Hukum Acara Pidana. Jakarta. Penerbit: Kencana.

Ruslan Renggong. 2019. Hukum Pidana Khusus. Jakarta, Penerbit: Prenadamedia Group.

E. Utrecht an Moch Saleh Djindang. 1983. Pengantar Dalam Hukum Indonesia. Sinar Harapan. Jakarta.

E. Utrecht. 1986. Hukum Pidana I. Surabaya: Pustaka Tinta Mas.

Kitab Undang-Undang Hukum Pidana.

Lamintang, P.A.F. 1984. Dasar-Dasar Hukum Pidana Indonesia. Bandung: Sinar Baru.

Lamintang, P.A.F. 1986. Hukum Panitensir Indonesia. Bandung: Aremico.

Leden Marpaung. 1996. Kejahatan Terhadap Kesusilaan dan Masalah Prevensinya. Jakarta: Sinar Grafika.

Mahrus Ali. 2011. Dasar-Dasar Hukum Pidana. Jakarta: Sinar Grafika.

Mochamad Anwar. 1982. Hukum Pidana Bagian Khusus Jilid II. Bandung: Alumni.

Moeljatno. 1993. Asas-Asas Hukum Pidana. Jakarta: Rineka Cipta.

Muladi dan Barda Arief Nawawi. 1992. Teori-Teori Kebijakan Pidana. Bandung: Alumni.

Packer Herbert L. 1968. The Limit of Criminal Sanction. California: Stanford University Press.

Roeslan Saleh. 1983. Perubahan Pidana dan Pertanggungjawaban Pidana. Jakarta: Aksara Baru.

Sa'abah Marzuki Umar. 1997. Seks dan Kita. Jakarta: Gema Insani Press.

Satjipto Rahardjo. 1998. Bunga Rampai Permasalahan Dalam Sistem Peradilan Pidana. Pusat Pelayanan Keadilan dan Pengabdian Hukum. Jakarta.

Soedarto. 1986. Kapita Selekta Hukum Pidana. Bandung: Alumni.

Soekanto, Soerjono. 1984. Pengantar Penelitian Hukum. Jakarta: Universitas Indonesia.

Soemitro, H.R. 1988. Metodologi Penelitian Hukum dan Jurimetri. Jakarta: Ghalia Indonesia.

Soerjono Soekanto dan Sri Mamuji. 2006. Penelitian Hukum Normatif. Jakarta: Grafindo Persada.

Soesilo, R. 1974. KUHP Serta Komentar-Komentarnya Lengkap Pasal Demi Pasal. Bogor: Politeia.

Undang-Undang Republik Indonesia Nomor 8 Tahun 1981 Tentang Hukum Acara Pidana.

Waluyo, Bambang. 2000. Pidana dan Pemidanaan. Jakarta: Sinar Grafika.

Wirjono, Prodjodikoro. 1986. Tindak-Tindak Pidana Tertentu di Indonesia. Bandung: PT Eresco. 